\title{
Scientific Values Are Crucial for Lake Kinneret Management Design: Test Cases
}

\author{
Moshe Gophen ${ }^{1}$ \\ ${ }^{1}$ Kinneret Limnological Laboratory \& Migal-Scientific Research Institute, Kiryat Shmone, Israel \\ Correspondence: Moshe Gophen, Migal-Scientific Research Institute, Kiryat Shmone, POB 831, 11016, Israel. \\ Tel: 972-469-53-556. E-mail: Gophen@migal.org.il
}

Received: December 9, 2015

Accepted: December 23, 2015

Online Published: January 11, 2016

doi:10.5539/emr.v5n1p12

URL: http://dx.doi.org/10.5539/emr.v5n1p12

\begin{abstract}
The concept of combined scientific information and objectivism, and carefulness prevention, are crucially required for the design of Lake Kinneret ecological services management. The integration of ecological structure and management is an assets of permanent value. Three test cases of that concept as incorporated within the usage policy of Lake Kinneret are presented and criticized. It is discussed through an insight into three cases of decision making process: 1) Nutrient dynamics (N, P and N/P mass ration) and the first record of N2-fixerCyanobacterium bloom; 2) The impact of natural and anthropogenic activities on the decline and recovery of Tilapias fish population; and 3) The consequences of water level decline on their quality. The objective of the paper is to improve both, safety and sevices of the ecosystem.
\end{abstract}

Keywords: Kinneret, ecological service, cyanobacteria, fishery, Water Level

\section{Introduction}

The management and design of Lake Kinneret (in Northern Israel), deserves a wide range of acceptance and agreement, between the public's ambition and formal authorized managers, legislators, and scientists within a formulated scope of a "golden pass". The principle objective of this achievement, is to constructively bridge the gap between public demands and ecological rules. The public's desire, is correlated with the way of life and welfare of the people, while the ecological requirements, are scientifically born rules. One of the concluded principles of management, is known as "Carefulness Prevention" (CP). Using three practical cases, the issue of $\mathrm{CP}$ as incorporated into the struggle for scientific justification, will be discussed. This paper is aimed at the need for ecological services to be implemented by the human society, combined with the required scientific conclusions. It is most likely that, the reasonable level of freedom for incomplete achievement of the CP implementation will be applied. Three test cases from the history of the ecosystem management of Lake Kinneret, were used for the analysis of the dispute between the ecological results, and public demands. Ecological management is a complicated issue where several principles are involved, but not necessarily fully integrated. Sometimes in the modern free democratic human societies, the integrative approach is met with a very strong objection. Under such conditions, the debate is full of scientific paradigm, and data are used by both sides of the disagreement. The precondition is usually used and the split is actually between two unbalanced sides, which are supported by a similar scientific background-ecological science. Those who protect the environment are usually stronger and better accepted by the public, but human beings deserve a way of life that is not completely dictated by science. Ecological rules are obviously not accepted as a preconditioned precedent. In the human society, terms like Ecological Services, which are given as welfare or way of life support to the public users of the relevant ecological systems, are recognized. Compromise and compensations are significant contributions to the required "golden pass" solution for those who are looking for a way of bridging the gap between scientific ecology, and ecological services paradigms. As an integrated matter within those realities, scientific objectivism is met. Cases of late recognition of scientific discoveries are well known worldwide. The book "De Revolutionibus" by Copernicus (the Heliocentric Discovery), was published and submitted to Pope Paulus III, shortly before the author's death. The author also wrote a dedication in the book, where he asked Pope Paulus III to ignore predicted negative responses from the public. The Galileo Galilei's book about "Eppur Si Muvoe", was classified as "Prohibition" (the author capitulated and survived), but was approved by the Catholic Church Authority 350 years later (1992). 


\section{Results and Discussion}

The publicity of the information presented in this paper, is far from the global level of interest of the discoveries of Copernicus and Galilei, but it is very valuable to the local conditions, and significant for the implementation of scientific conclusions elsewhere. The three cases are: 1) The outbreak of N2-fixer-Cyano-Bacterium; 2) Fishery management; 3) Low water levels.

\subsection{Case I}

Aphanizomenon ovalisporum (Fori) (Figures 1, 2, 3, 4 \& 5)
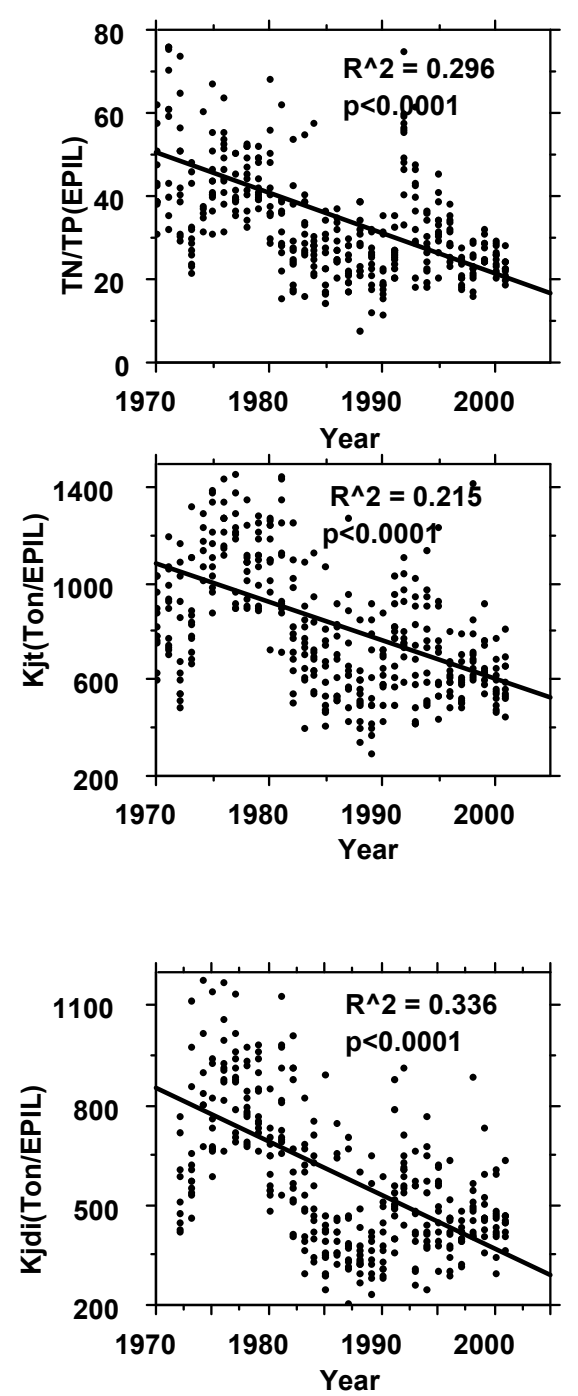

Figure 1. Epilimnetic loads (t) of TIN, TN, TDN and TN/TP mass ratio in Lake Kinneret (1974-2004)

Loads Vs Years 

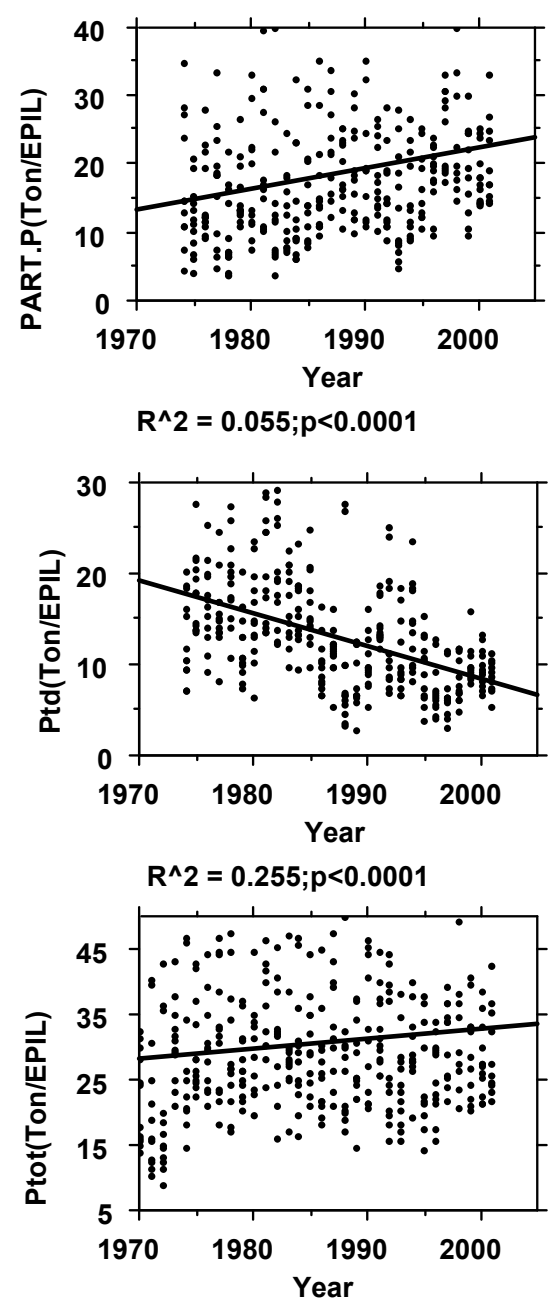

$R^{\wedge} 2=0.015 ; p=0.0144$

Figure 2. Epilimnetic loads ( $t$ ) of Phosphorus: TP, TDP, Particulate P in Lake Kinneret (1974-2004) Loads ( $\mathrm{t}$ ) Vs Years

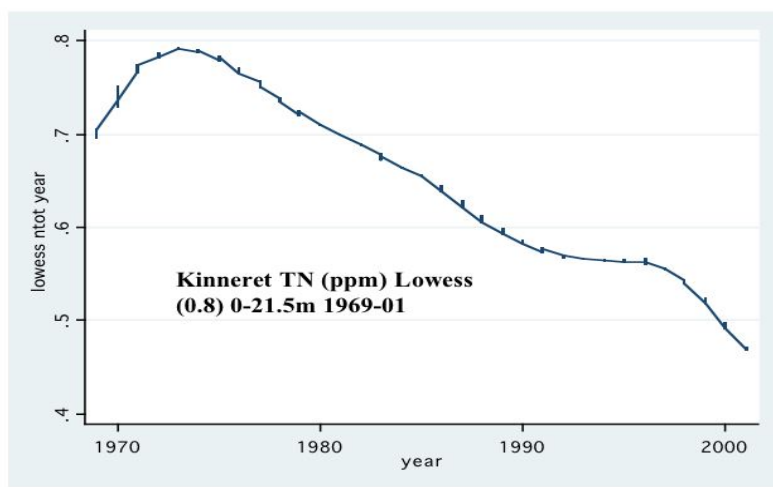

Figure 3. TN concentration (ppm) in the Epilimnion of Lake Kinneret 


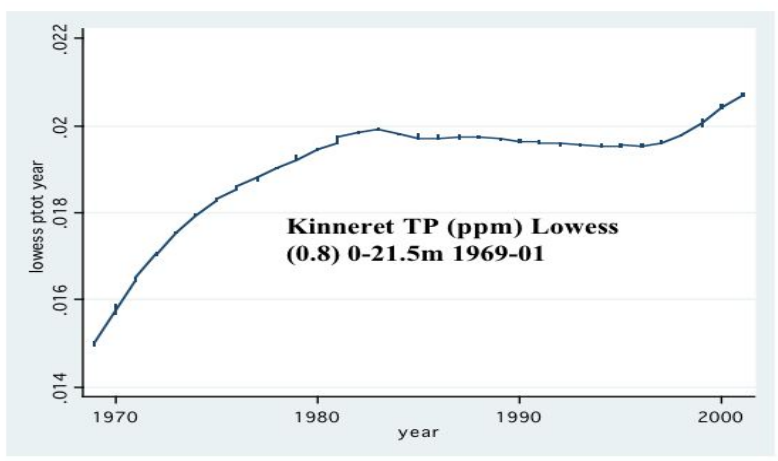

Figure 4. TP concentration (ppm) in the Epilimnion of Lake Kinneret

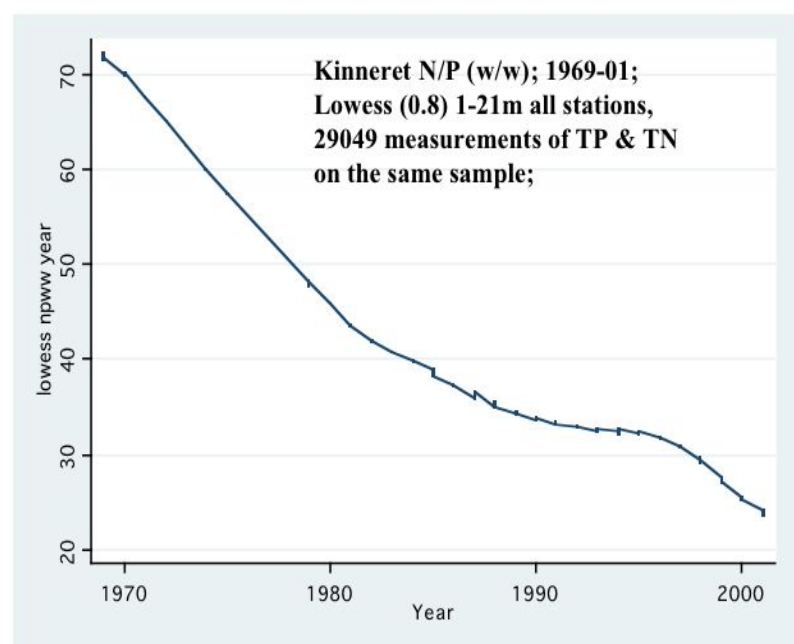

Figure 5. Epilimnetic TN/TP mass ration in Lake Kinneret Vs Years

In the summer (September-October) of 1994, a heavy bloom of the N2 Fixer-filamentous-heterocystous cyanobacterium, Aphanizomenon ovalisporum (Forti), was recorded for the first time in Lake Kinneret (Gophen, 1999, 2015a, 2015b; Gophen et al., 1999). Our study started 7 years earlier, in the summer of 1987. Long term analysis of the epilimnetic $\mathrm{N}$ and $\mathrm{P}$ loads in the Epilimnion of Lake Kinneret (Figure $1 \&$ 2), indicated a decline of $\mathrm{N}$ and a slight increase of $\mathrm{P}$. The long term decline of Nitrogen load in the Epilimnion of Lake Kinneret (Figure 3) and the moderate elevation of Phosphorus (Figure 4) resulted in a prominent decline of the N/P mass ratio (Figure 5) in the Kinneret Epilimnion. An alarm was signalized, and it was aimed at the options for the existence of a suitable condition for the growth of Nitrogen Fixers Cyano-Bacteria (Gophen, 1999). This alarm of enhanced Blue-greens, became a high priority of the author's activities: The issue was first presented at the annual meeting of the Israeli Society of Ecology, then it was followed by publications in local and international magazines and journals, as well as lectures on it, in national and international conferences. The scientific response of the community closely related to it was negative, and they denied and objected to the claim, blaming the author of raising a false alarm. It was replaced by a search for other potential parameters ( $\mathrm{Cu}$ for example) as the cause of the bloom. Seven years later (1994), the N2 fixers appeared. As is common in science, the significant enhancement of the study of N2-fixer cyanophytes invasion on Lake Kinneret, was stimulated by the Key-stone paper (Smith, 1983). As was expected from a scientific methodology, a concluded scientifically based conclusion was presented to water authorities about the optimal condition of the Cyano-bacterial proliferation in Lake Kinneret, and consequently a struggled efforts were achieved to convince water managers to be aware about the risk to the quality of the Kinneret water. It was carried out through the forms of International and National Conferences, Published Papers, lectures, workshops and others. But it was rejected by the water authorities. Among many scientific publications (Barica et al., 1980; Flet et al., 1980; Liano, 1977; McQjueen \& Lean, 1987; Shapiro, 1973; Smith, 1982, 1983; Stockener \& Shortreed, 1988), a comprehensive study of the 
important priorities of the ecological factors, which enhanced the development of N2 fixing Cyanobacterium, was documented by Zofia et al. (2015). They concluded that the best explanation for variations among lakes in the rate of Cyanobacteria enhancement, was due to nutrient (P, N) concentrations (Havens et al., 2003; Smith, 1982, 1983). The conceptual merit of earlier studies, initiated a logical paradigm of a backward model: P for removal, $\mathrm{N}$ for fertilizing, or both of them used as a tool for Cyanobacteria suppression. The first record of the A. ovalisporum outbreak (1994), was after a long term decline in the N/P mass ratio, and was therefore, an important subject to carry out a Nitrogen fertilizing research on. The community's response to this was a great disappointment of ignorance. Unfortunately, the $\mathrm{N}$ decline, a slight enhancement of the $\mathrm{P}$, and the decrease in the $\mathrm{N} / \mathrm{P}$ ratio were not regarded as the reasons for the burst of the N2 fixers. Three years later, the limnologist community agreed on the N/P ratio factor, but the precautions given by the author earlier were rejected by the community. Scientific credit ignorance is tolerable, but, one of the scientific assets of permanent value was broken in this case. Moreover, since the consequence of N2 fixers Cyano-Bacteria in a drinking water supply reservoir deteriorated, earlier awareness would have been helpful. This case represents a scientific discovery and the scientist's stubbornness in late implementation. Thus, "Carefulness Prevention" was replaced by solid scientific conclusion.

\subsection{Case II}

Fishery Crisis of Tilapia and its recovery (Figures $6 \& 7$ ).
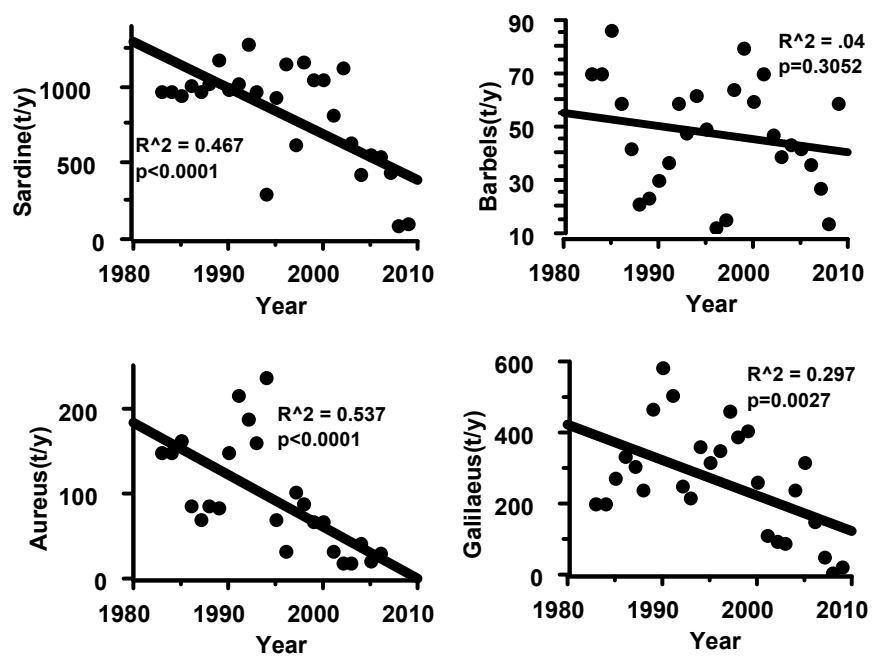

Figure 6. Annual (1980-2010) landings (t/y) Vs Years of Tilapias, Sardine, and Barbels in Lake Kinneret

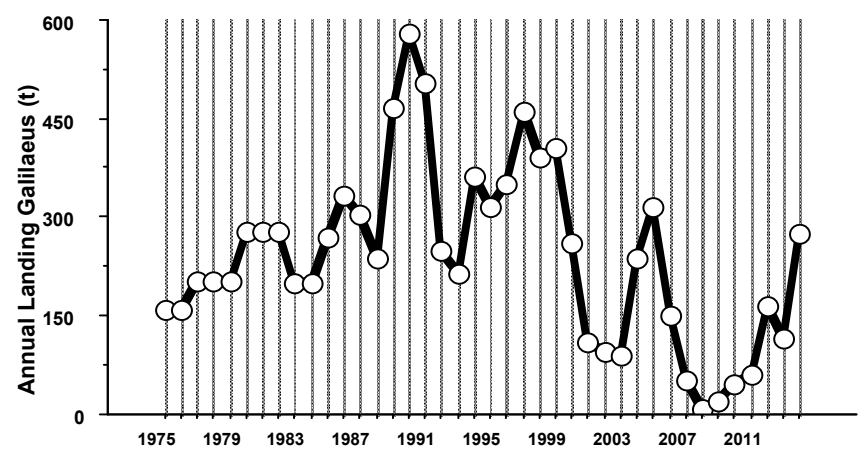

Figure 7. Sarotherodon galilaeus annual landings (t/y)

In the last 20 years, the Kinneret ecosystem structure has undergone significant modifications (Gophen, 2014a, 2015a; Gophen et al., 2015). The algal dominance of the bloom that formed Pyrrhophyte Peridinium, was replaced by Cyanobacteria, and the fish food resources were modified, respectively. Other independent 
constrains enhanced the pressures on the fishery: Increase in the population size of the fish predator, the Great Cormorant (Phalacrocorax carbo), a reduction in the stock of Tilapia fingerlings, the illegal use of small mesh size fishing nets, Bleaks fishing stopped, and the outburst of a viral disease, which infected the Sarotherodon galilaeus and the Tristramella simonis simonis. The annual landings of Tilapias, S. galilaeus, Oreochromis aureus and Tristramella simonies simonis decreased from 350 t/y during the 1970's, and 300-500 t/y during the 1980's to 8 tons in 2008 (Figure 6) and that of S. galilaeus alone, from 300-400 t/y during the 1990's to $8 \mathrm{t} / \mathrm{y}$ in 2008 but later was recovered and increased (Figure 7).

An emergency ad-hoc meeting (the author was not invited) was conducted and by a resolution, it was concluded that fishing activities in Lake Kinneret, should be stopped completely, for three years. The author in collaboration with a group of scientists, vehemently opposed this resolution. They indicated the crisis factors and later, the ban on fishing was lifted, but with a recommendation that the fishing activities should be controlled by legal legislations, which had been implemented earlier. The scientists accepted this resolution, and a new governmental resolution was formed. Five years after the crisis of the S. galilaeus fishing, their population recovered and landings were renewed up to the earlier level.

During 2007-2008, the landings of S. galilaeus sharply declined from the marketing of 200-400 tons annually, to less than 10 tons in 2008. We indicated several reasonable factors which affected this decline (Gophen et al., 2015):

1) Reduction of S. galilaeus stocking from $2-3 \times 10^{6}$, to $0.8-0.9 \times 10^{6}$ per year;

2) The use of illegal small mesh size ( $0.72 \mathrm{~cm}$ of "knot to knot") fishing nets;

3) Ecological changes within the structure of the Kinneret ecosystem, which led to the disappearance of the bloom forming dinoflagellate Peridinium and its replacement by Cyanobacteria;

4) Proliferation of the Bleaks (Cyprinidae, Mirogrex terraesanctae terraesanctae, Acanthbrama lissneri; Lavnun; Kinneret Bleak), resulted in a complete elimination of market demands, as well as several years of optimal reproductory condition. The outcome was a competition between Bleaks and S. galilaeus, for their zooplankton food resources;

5) An outburst of a viral disease that infected the S. galilaeus and Tristramella simonis simonis (TilV-RNA-NODA-the blindness disease);

6) Intensification of the Cormorant predation of the sub-commercial sizes of S. galilaeus; Cormorant density was increased to $7-10 \times 10^{3}$ per season (October-March), which was accompanied by approximately 200-300 tons of annual Tilapia preys;

7) Natural cyclic fluctuations of the S. galilaeus stock. The Bleaks' increase and the Tilapias' decline, are correlated with EL-NIÑO/Southern Oscillation (ENSO);

8) Fishing operation and the behavior of the fish under pressure were highly related: the heavy fishing pressure on S. galilaeus, which was initiated by the fishermen and the Cormorant, caused an essential migration of the fish shoals to find a refuge in deeper layers, making its detection and capture more difficult.

These factors coupled with a shift in fishery to Tilapias (while Bleaks fishing was independently targeted on market demand) made the overall regulation a complicated objective.

The fishery design in Lake Kinneret is aimed at both, fishermen's income and water quality protection. Nevertheless, the optimization of the fishery management, crucially includes a comprehensive involvement of a wide range of ecological structure, where fishermen's income, nature conservation, and water quality protection are integrated. The wider the consideration accounted for, the more acceptance level achieved. The ad-hoc's resolution of an immediate stop to fishing, was replaced by a deeper and wider consideration. This type of approach is optimal in integrating ecological services, society's demands, and natural components. "Carefulness Prevention" which was replaced by solid scientific conclusion, aimed at human welfare and nature preservation. 


\subsection{Case III}

2.3.1 Water Level Decline and Availability for Supply (Figures 8, 9, 10 \& 11)

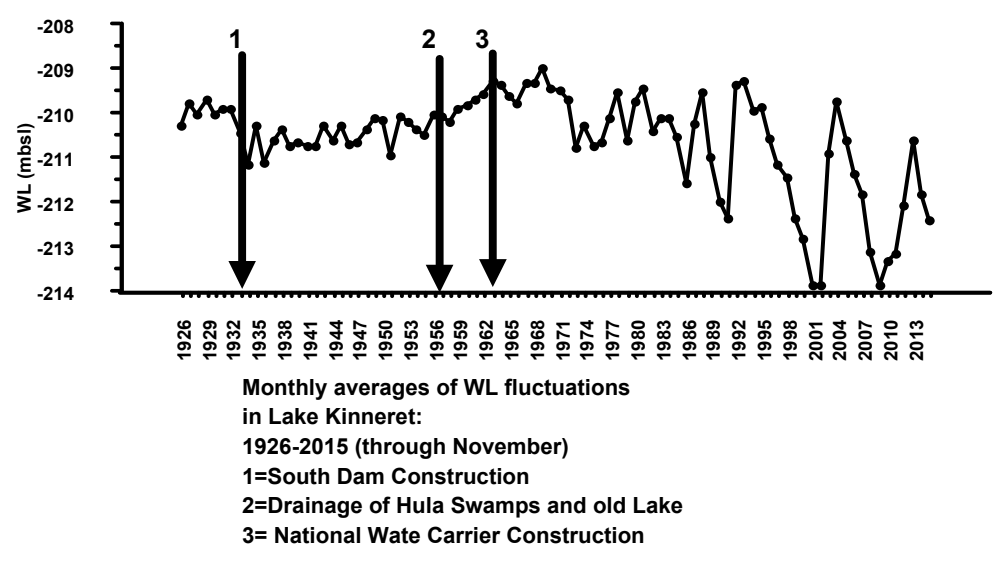

Figure 8. WL fluctuations (monthly averages) in Lake Kinneret (1926-2015)

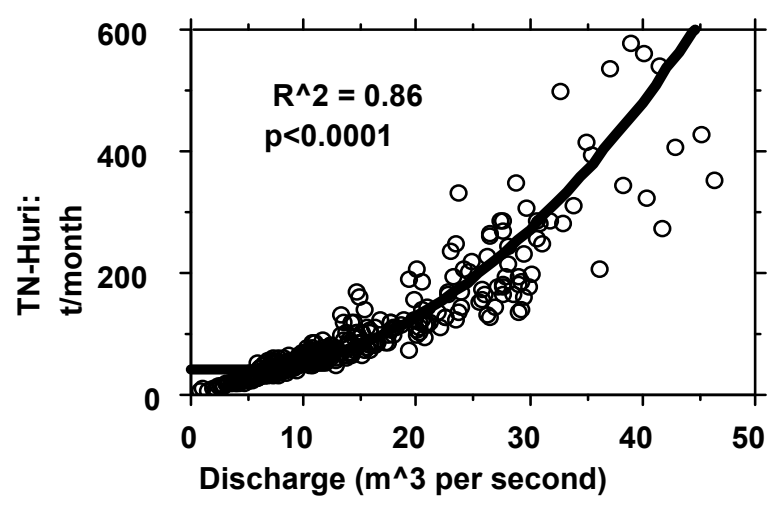

Figure 9. Jordan discharges Vs TN load fluxes (ton/month): $\mathrm{r}^{2}$ for other nutrients: TP-0.596, TIN-0.776, $\mathrm{SO}_{4}-0.816$, Org. $\mathrm{N}-0.606$, Chloride- 0.886 (all: $\mathrm{p}<0.0001$ )

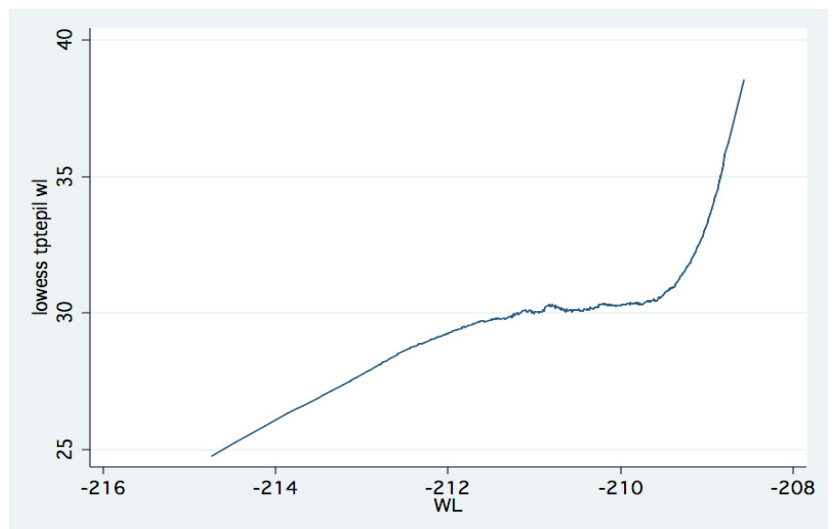

Figure 10. Epilimnetic Loads (tons) of TP Vs WL in Lake Kinneret 


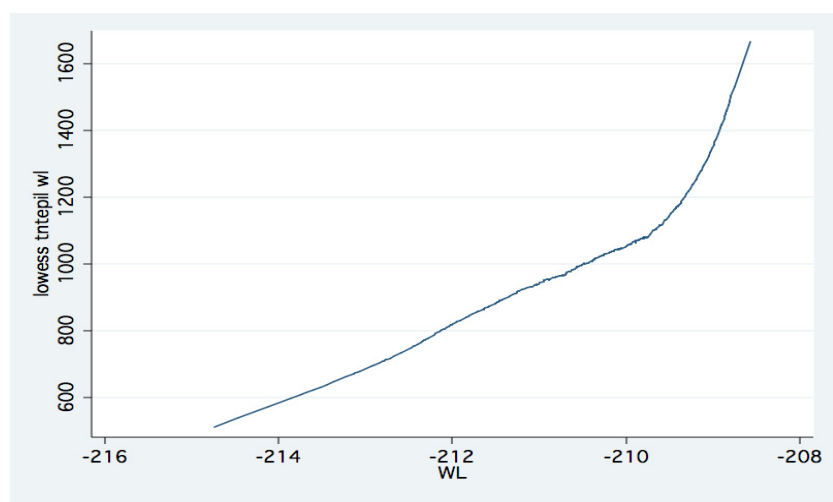

Figure 11. TN (ton/Epilimnion) Vs WL in Lake Kinneret

Lake Kinneret is the only natural freshwater lake in Israel. The climate conditions in northern Israel are sub-tropical: short, wet and cold winter, and, long, dry and warm summer. Above $95 \%$ of Israel's natural water resources are utilized, and the only options available are reuse and desalinization. The total precipitation in Israel is $7.9 \mathrm{bcm} / \mathrm{y}$, and about $400-900 \mathrm{~mm} / \mathrm{y}$ in the Kinneret drainage basin. The total water supply of Israel is 2.11 $\mathrm{bcm}$, of which $0.55 \mathrm{bcm}$ is from the Kinneret-Jordan system. Thirty percent $(0.750 \mathrm{bcm} / \mathrm{y})$ of the supplied waters which are at drinking quality level, are for domestic consumption. The Average Water budget for Lake Kinneret (before the operation of Desalinization plants), is $\left(10^{6} \mathrm{~m}^{3} / \mathrm{year}\right.$; mcm/year). The breakdown of the budget $(\mathrm{mcm} / \mathrm{year})$ is given below:

Inputs:

Rivers- 725

Direct Rain-75

Total -800

Output:

Evaporation-280

Supply to NWC (National Water Carrier) (mostly for domestic demands and partly to agricultural irrigation and minority to Industry) -380

Outflow-80;

Local Consumers-60;

Total-800.

If the annual inflow/outflow budget is balanced, the Water Level (WL) does not change annually. Two optional conditions for WL decline are relevant: 1) a Decrease in the precipitation regime, as has happened since the mid 1980 's with several exceptions, and pumping rate is not reduced; 2) Pumping enhancement. Nevertheless, WL fluctuation is a mixed issue of scientific indication (its impact on water quality), hydrological services (water supply), and human welfare (recreation and living infrastructure), and it measures the places where the ecological services scope is dominant.

\subsubsection{Historical Aspects}

In 1933, the south end of the lake was blocked by a dam, which was a part of the Hydroelectric Plant system located $10 \mathrm{Km}$ South of the lake. During the 1950's, the National Water Carrier (NWC) was constructed, for the transportation of about $1 \times 10^{6} \mathrm{~m}^{3}$ of Kinneret waters, including 250 tons of Sodium Chloride and the WL was fluctuated respectively (Figure 8). The supply started by pumping in the Northwest region of the Lake. Since then (1950's), the Kinneret was designated to serve as a major source of domestic supply. Recently (2010), sea water desalinization was almost exclusively designated for domestic supply, and the role of the Kinneret component was dramatically reduced. Since 1933, the Kinneret outflow has been controlled by the impact of national demands on the lake management policy, and has been limited by hydrological, limnological, and environmental constrains. During the last 49 years, the NWC system withdrew approximately $15 \mathrm{bcm}$ of water from the lake (ca 3.8 times the lake volume), for drinking, agriculture, industry and aquifer recharging. What are the upper and lower limits of WL fluctuations (Figure 8) (Gophen, 2014b)? The upper limit (208.8 mbmsl) was 
set, in order to avoid damage to the existing constructions that were aimed at eliminating fees of financial compensations to potential damages. The lower limit is more flexible and presently, it is set at $213 \mathrm{mbmsl}$. The appointment of the lower limit is based on the scientific knowledge of its impact, on the water's quality. As a result of WL restriction management, about $4 \mathrm{bcm}$ were not used, but were released through the south dam to the Jordan River, and into the downstream Dead Sea. The salinity of the Kinneret waters fluctuates regularly: it had $300-330 \mathrm{ppm}$ of chloride before 1960, 400ppm in the early 1960's, and 200-210ppm, in the early 1980's. Then it gradually elevated to $250-300 \mathrm{ppm}$. Therefore, Lake Kineret, became a significant supplier of salts to the Israeli soils and aquifers. About 9 million tons of dissolved salty Ions $\left(\mathrm{Cl}, \mathrm{CO}_{3}, \mathrm{Na}, \mathrm{Mg}, \mathrm{K}, \mathrm{Ca}, \mathrm{SO}_{4}\right)$, deteriorated the soils' and aquifers' qualities in the southern part of Israel, from 1964-2005. A dispute between the scientists and decision makers, which was accompanied by national extensions that was never clearly settled is: How low can WL can be? The WL is controlled by the precipitation regime, and pumping through the NWC and supply to the local consumers is possible, because evaporation is stable. Actually, the optimal operation of the NCW includes to close the dam, in order to achieve maximum storage. It is likely that the closed dam policy might be disadvantageous. Before the construction of the dam, nutrient rich winter input floods crossed the upper layers of the lake, and this resulted in an increase in the temperature of the floods, and it was higher than that of the Epilimnetic waters. The floods left naturally, through the open outlet.

Closed dam management, enhanced nutrient retainment in the hypolimnion and the sediments. The withdrawal of water, is done by pumping from the upper layers. Therefore, in comparison with the "no dam" condition, the "closed dam" management might enhance nutrient accumulation. Moreover, the winter demands for supply are lower than the summer, therefore, additional retainment of nutrients in the lake sediments is predicted, because in winter, the nutrient concentrations are higher. But this was not the case in Lake Kinneret and no pollution trend was indicated, in relation to the phenomenon. The annual retention time of water in Lake Kinneret is 5.6 years at the maximum storage, and this has to be considered. So far, what is the bottleneck of such a complicated structure and its management? The answer is the regime of supply. Although water supply has several extensions, a scale of priority in this format, is crucially required: drinking (Domestic), agriculture and industry, human usage for fishery, recreation, tourism, and those living in the close vicinity. Before the desalinization era the domestic supply was the top priority, but presently, the lake system is more open for ecological services. Conclusively, the priority considerations are referred to as the pre-desalinization era. Undoubtedly, without solid information (data), none of the scaled priorities can be appointed, until the relevance of CP is justified. But this was not the case when a sensitive situation put the scientists and decision makers in a dilemma. After several years of drought, the water supply conditions created an indispensable decision to decide upon agricultural restriction, or that WL be lowered to a level that had never been experienced before, that is, below $214.5 \mathrm{mbmsl}$. In such a case, the CP paradigm is relevant only if available data are in existence. The available data indicated that under the drought regime, river inflows reduced, as well as nutrient inputs (Figure 9). Due to the reduction in nutrient inputs, the quality of the epilimnetic water was improved (Figures $10 \& 11$ ), and this resulted in the supported recommendation a sligh WL lowering aimed at prevention of uprooting Avocado trees in the country. This WL additional decline, made it possible for the Avocado plantations to survive. Avocado is known to be a high water consumer and uprooting them, will cause insufficient marketing for the next several years. The decline in WL, which meant an additional availability of water, was implemented, and the lake water's quality was not deteriorated. A pure scientific approach might indicate an option for limnological devastation, but in reality, the opposite was achieved. Conclusively, "Carefulness Prevention" was replaced by solid scientific data, and agricultural products survived.

\section{Conclusion}

Three cases of possible contradiction between "Carefulness Prevention" and Scientific values are presented: 1) Nutrients dynamics and enhancement of cyano-bacteria; 2) Fishery management and 3) Water level decline. In those three cases there is solid awareness to prevent deterioration of water quality. High priority is also given to society welfare of tourism and recreation as well as fisher income. The paper describes parameters of hesitation but solution for management achievements are suggested. These three cases represent the ultimate need for appropriate scientific information as background for the optimal implementation. If significant signal such as $\mathrm{N}$ and $\mathrm{P}$ composition in the epilimnion is signaled, practical measures supposed to be taken; If fishery biology of Tilapias combined with relevant scientific information is available, rejection is incorrect to and even government resolution of fishing stop could be prevented; If a comprehensive analysis of the impact of WL decline on water quality agricultural crops restriction might be prevented (as already occured). The outcome of this paper is: Do not reject information and imply a comprehensive consideration. 


\section{Reference}

Barica, J., Kling, H., \& Gibson, J. (1980). Experimental manipoulation of algal bloom composition by Nitrogen addition. Can. J. Fish. Aquat. Sci., 37, 1175-1183. http://dx.doi.org/10.1139/f80-150

Flett, R. J., Schindler, D. W., Hamilton, R. D., \& Campbell, N. E. R. (1980). Nitrogen Fixation in Canadian Precambrian Shield Lakes. Can. J. Fish. Aquat. Sci., 37, 494-505. http://dx.doi.org/10.1139/f80-064

Gophen, M. (1999). Prediction of an N2-fixing cyanobacteria bloom in Lake Kinneret (Israel) based on N and P balance. Verh. Internat. Verein. Limnol., 27, 1239-1242.

Gophen, M. (2014a). Land-Use, Albedo and Air Temperature Changes in the Hula Valley (Israel) during 1946-2008. Open Journal of Modern Hydrology, 4(4), 101-111. http://dx.doi.org/10.4236/ojmh.2014.44010

Gophen, M. (2014b). The Impact of Water level decline on water Quality in the Epilimnion of Lake Kinneret (Israel): Perennial Perspectives. Open Journal of Ecology, 4, 892-906. http://dx/doi.org./10.4236/oje.2014.4140755

Gophen, M. (2015a). The Impact of Available Nitrogen Deficiency on Long-Term Changes in the Lake Kinneret Ecosystem. Open Journal of Ecology, 5, 147-157. http://dx.doi.org./10.4236/oje.23015-54013

Gophen, M. (2015b). Experimental study of the Aphanizomenon ovalisporum response to Nitrogen fertilization in the Sub-Tropical Eu-Meso-trophic Lake Kinneret (Israel). Open Journal of Ecology, 5, 259-265. http://dx.doi.org/10.4236/oje.2015.56020

Gophen, M., Smith, V. H., Nishri, A., \& Threlkeld, S. T. (1999). Nitrogen deficiency, phosphorus sufficiency, and the invasion of Lake Kinneret, Israel, by N2-fixing cyanobacterium Aphanizomenon ovalisporum. Aquatic Sciences, 1, 1-14. http://dx.doi.org/10.1007/p100001326

Gophen, M., Sonin, O., Lev, M., \& Snovsky, G. (2015). Regulated Fishery is Beneficial for The Sustainability of Fish Population in Lake Kinneret (Israel). Open Journal of Ecology, 5, 513-527. http://dx.doi.org/10.4236/oje.2015.510042

Havens, K. E., James, R. T., East, T. L., \& Smith, V. H. (2003). N:P Ratios, light limitation and Cyanobacterial dominance in a subtropical lake impacted by non-point source nutrient pollution. Environmental Science \& Technology, 37(9), 1713-1719. http://dx.doi.org/10.1016/s0269-7491(02)00304-4

Liao, C. F. H. (1977). The effect of nutrient enrichment on nitrogen fixation activity in the Bay of Quinte, Lake Ontario. Hydrobiologia, 56, 273-279. http://dx.doi.org/10.1007/BF00017515

McQueen, D. J., \& Lean, D. R. S. (1987). Influence of water temperature and nitrogen to phosphorus ratios on the dominance of blue-green algae in Lake St. George, Ontarion. Can. J. Fish. Aquat. Sci., 44, 489-699. http://dx.doi.org/10.1139/f87-073

Shapiro, J. (1973). Blue-green algae: Why they become dominant. Science, 179, 382-384. http://dx.doi.org/10.1126/science.179.4071.382

Smith, V. H. (1982). The Nitrogen and Phosphorus dependence of algal biomass in lakes: An experimental and theoretical analysis. Limnol. Oceanogr., 27, 1101-1112. http://dx.doi.org/10.4319/lo.1982.27.6.1101

Smith, V. H. (1983). Low Nitrogen to Phosphorus ratios favor dominance by blue-green algae in lake phytoplankton. Science, 221, 669-671. http://dx.doi.org/10.1126/science.221.4611.669

Stockener, J. G., \& Shortreed, K. S. (1988). Response of Anabaena and Synechococcus to manipulation of Nitrogen: Phosphorus ratios in lake fertilization experiment. Limnol. Oceanogr., 33(6 part 1), 1358-1361. http://dx.doi.org/10.4319/lo.1988.33.6.1348

Zofia, E., Taranun, E., Gregory, P. R., Leavitt, T., Buchaca, J., Katalan, P., ... Vinerbrook, R. D. (2015). Acceleration of Cyanobacterial dominance in North temperate-subarctic lakes during the Anthropocene. Ecology Letters, 1-10.

\section{Copyrights}

Copyright for this article is retained by the author(s), with first publication rights granted to the journal.

This is an open-access article distributed under the terms and conditions of the Creative Commons Attribution license (http://creativecommons.org/licenses/by/3.0/). 